Sarp, N. (2018). Effects of War and Forced Migration on Child Health and Development. Journal of Academic Perspective on Social Studies, (1), 35-40.

\title{
EFFECTS OF WAR AND FORCED MIGRATION ON CHILD HEALTH AND DEVELOPMENT
}

\section{"Syria war: 2016 deadliest year yet for children" UNICEF}

\begin{abstract}
In the $21^{\text {st }}$ century, unfortunately millions of children and young people worldwide are affected by forced migration, and war.

Children and young people are confronted with physical harm, violence, danger, fear and loss. It affects their health, and development, and this problem will continue increasingly. In this article, these effects have been examined, and the responses according to the developmental level, personality of the child and the situation has been discussed.
\end{abstract}

Key Words: War, Forced Migration, Child Health, Child Development.

\section{INTRODUCTION}

Wars are the worst events in human history, unfortunately since the beginning of time, there have been wars and the most vulnerable groups have always been children, women, elderly people and people with disabilities.

While humanity is longing for peace, unfortunately still, wars continue in the $21 \mathrm{st}$ century. Especially in the under developed/developed countries, never-ending wars are continuing increasingly, and wars cause forced migrations.

Migration is defined as; "Movement of people to a new area or country in order to find work or better living conditions " in Oxford dictionary. As to another definition of migration is belong to International Organization for Migration (IOM). It is; "The movement of a person or a group of persons, either across an international border, or within a State. It is a population movement, encompassing any kind of movement of people, whatever its length, composition and causes; it includes migration of refugees, displaced persons, economic migrants, and persons moving for other purposes, including family reunification".

Migration for better living condition is acceptable, but forced migration is unacceptable. Millions of people are currently uprooted, and the worldwide refugee population will continue to rise continuously.

The 1951 United Nations Convention Relating to the Status of Refugees (Geneva Convention) defines a refugee as someone who has a "well-founded fear of persecution for

\footnotetext{
${ }^{1}$ İstanbul Bilgi Üniversitesi, Turkey, nilgun.sarp@ bilgi.edu.tr, ORCID ID: https://orcid.org/0000-000206714-4848
} 
reasons of race, religion, nationality, membership of a particular social group or political opinion', (UNHCR 1951).

\section{WAR AND CHILDREN}

Children are more than half of the world's displaced population. In this mercilessly world, millions of children have been killed, wounded, and orphaned in conflicts.

According to the United Nations Children's agency report, approximately 50 million children in the world are refugees, migrants or without a home, $8 \%$ of these children need specialist care and 10,400 children are unaccompanied or separated from their parents, more than 52\% are in school age and cannot attend school (UNICEF, 2016).

Another warning was from European Police Organization (EUROPOL). They warned that more than 10 thousand immigrant children in the last two years have been lost since they were registered in the country, and that these children may be forced into sex work and slavery by gangs. According to United Nations statistics (y1), children are 50 percent of human trafficking in the world and the most suitable age for trafficking is 18 years. They may have been abducted for use in human trafficking (www.bbc.com).

War has various effects on children's bio psychosocial developments. Firstly, they are dependent on their caregivers; secondly, they lose their opportunity for education, force to move into refugee or displaced person camps, and they have so many risks in their new life. According to "Convention on the rights of the child", Article 38 (UNICEF);

1. States Parties undertake to respect and to ensure respect for rules of international humanitarian law applicable to them in armed conflicts which are relevant to the child.

2. States Parties shall take all feasible measures to ensure that persons who have not attained the age of fifteen years do not take a direct part in hostilities.

3. States Parties shall refrain from recruiting any person who has not attained the age of fifteen years into their armed forces. In recruiting among those persons who have attained the age of fifteen years but who have not attained the age of eighteen years, States Parties shall endeavour to give priority to those who are oldest.

4. In accordance with their obligations under international humanitarian law to protect the civilian population in armed conflicts, States Parties shall take all feasible measures to ensure protection and care of children who are affected by an armed conflict.

The impacts of war and being a refugee on children are as follows (Barbara,2006: 891);

1-Death

2-Injury,

3- Disability.

4- Illness

5- Rape and prostitution for subsistence

6- Psychological suffering

7- Moral and spiritual impacts

8- Social and cultural losses

9- Child soldiers 
Children are affected mostly when parents are killed, harmed and terrified, but when danger ends and the basic needs of children are met, they show extraordinary healing and recovery abilities. Responses are different according to the developmental level, personality of the child and the situation, but all of them will experience anxiety, and panic. Examples of Age Differences are given in the tables below-Compiled by Ann Masten (https://melissainstitute.org/documents/effectsofwar.pdf).

\section{Infants \& Toddlers( (0-2)}

\begin{tabular}{|l|l|}
\hline Vulnerabilities, Common Symptoms & Assets and Protective Factors \\
\hline Very sensitive to quality of care & Responsive to adult care \\
\hline Severe separation distress, crying & Comforted by attachment figures \\
\hline Clinging, sleeping and eating problems & Likely to elicit adult intervention \\
\hline Sensitive to emotions of caregiver & Immaturity limits exposure \\
\hline
\end{tabular}

Key to intervention: Good care from consistent parent figures

\section{Preschoolers (3-6)}

\begin{tabular}{|l|l|}
\hline Vulnerabilities, Common Symptoms & Assets and Protective Factors \\
\hline Sensitive to quality of care \& change & Responsive to adult care \\
\hline Regression \& loss of new skills & Respond to routine, stability \\
\hline Believe they cause bad things to happen & Tolerate some separations \\
\hline Nightmares, fearfulness, vigilance & Can talk, understand stories \\
\hline Sensitive to visual images of horror & Can express through drawing \\
\hline Play shows trauma themes & Can play more independently \\
\hline
\end{tabular}

Keys to intervention: Good care, stability, routines, and play

\section{Young Schoolchildren (7-11)}

\begin{tabular}{|l|l|}
\hline Vulnerabilities, Common Symptoms & Assets and Protective Factors \\
\hline Awareness of death and injuries & Larger network of supports \\
Growing capacity for worrying & Can gather \& use information \\
\hline Disturbing thoughts and images & Hero and rescue fantasies \\
\hline Nightmares, sleeping problems & Can seek help more effectively \\
\hline Mutilation and bodily-harm fears & Can help others more \\
\hline Anger, aggression, irritability & Better at self-regulation \\
\hline Noncompliance, acting out & Friends \\
\hline Headaches, stomach aches & Structured activities \\
\hline School problems & School resources \\
\hline Depression, withdrawal & \\
\hline
\end{tabular}


Keys to intervention: Safety, monitoring, stable care \& routines, opportunities for self-efficacy, control, prosocial activities, peers

As it is seen in the tables, there are different vulnerabilities and common symptoms in different age groups, and assets and protective factors are also different in these age groups. These specifications can help professionals to support children under negative circumtances.

\section{FORCED MIGRATION AND CHILDREN}

As it is defined as ; "Movement of people to a new area or country in order to find work or better living conditions " in Oxford dictionary. However, migration has been a feature of human existence for centuries, humans have always migrated in groups and as individuals to escape hunger and poverty, to find new economic opportunities and employment, and to seek freedom from war and conflict.

International Organization for Migration (IOM) definition is;"The movement of a person or a group of persons, either across an international border, or within a State. It is a population movement, encompassing any kind of movement of people, whatever its length, composition and causes; it includes migration of refugees, displaced persons, economic migrants, and persons moving for other purposes, including family reunification".

Forced migration is unacceptable, but it is necessary in some conditons.

According to the IOM data, 65.3 million individuals were forcibly displaced worldwide due to persecution, conflict, generalized violence, or human rights violations, by the end of 2015. This is the greatest level of forced displacement ever recorded. The total figure includes 21.3 million refugees, 40.8 million internally displaced people and 3.2 million asylum-seekers. 19.2 million newly displaced by natural disasters across 113 countries during 2015. Turkey and Pakistan are the main refugee-hosting countries globally, and the refugees are from mainly Middle East, and former Russian countries (IOM).

Children have various risks or stressors in their development, but refugee children have the added traumatic stressors inherent, and traumatic experiences of displacement in the forced migration process (Brostein, Montgomery, 2011: 44-45).

The refugee children have problems such as food, shelter, education, and mental health remains mostly unresolved. Risk factors for mental health problems in refugee children are as follows (Fazel, Stein, 2002:367). ;

\section{Parental factorsis:}

Post-traumatic stress disorder (PTSD) in either parent

Maternal depression

Torture, especially in mother

Death of or separation from parents

Direct observation of the helplessness of parents

Underestimation of stress levels in children by parents

Unemployment of parents

\section{Child factorsis}

Number of traumatic events - either experienced or witnessed

Expressive language difficulties

PTSD leading to long-term vulnerability in stressful situations 
Physical health problems from either trauma or malnutrition

Older age

\section{Environmental factors}

Number of transitions

Poverty

Time taken for immigration status to be determined

Cultural isolation

Period of time in a refugee camp

Time in host country (risk possibly increases with time)

A Multiple-Case Study on Developmental Screening of Syrian Children was done in Turkey. The participants of the study consisted of 53 Syrian refugee children between the ages of 0 - 6 and their families from Sultanbeyli a district of İstanbul. Data was collected by observation, interviews and using a developmental check list.After analysis of the data the results demonstrated that, children performed the highest score in motor development and selfcare skills. However, the lowest scores were in cognitive skills. Based on this information, it was suggested that the essential prevention and intervention programs could be developed in line with the needs of Syrian children (Korkut, Temel, Sarp, 2016).

\section{CONCLUSION}

Effects of war and forced migration on child health and their development are crucial. Unfortunately, this problem will continue increasingly.According to Unicef latest data; 5.8 million Syrian children are in need inside Syria, $2.8 \mathrm{~m}$ trapped in hard-to-reach areas, 281,000 living under siege, $2.3 \mathrm{~m}$ have fled the country.

This is a global problem, andshould be governed at the internationallevel.An universal protection system should be addressing the shortcomings of the plight these children face.

If all kinds of problems, such as; psychological, emotional, and physical of the refugee children are not addressed today, they may generate other problems in the future both for themselves and for their society.

As a summary, in two-faced world, there is an interesting dilemma. Nominations for the 2016 Nobel Peace Prize, there were 376 candidates that out of which 228 are individuals and 148 are organizations. The highest number of candidates ever!!!

\section{REFERENCES}

Barbara, J.S. (2006), Impact of War on Children and Imperative to End War, Croat Med.J. Dec; 47(6): 891-894

Fazel M, Stein A. The Mental Health Of Refugee Children. Archives of Disease in Childhood 2002; 87:366-370.

Korkut, E., Temel, M., Sarp, N. A Multiple-Case Study on Developmental Screening of Syrian Children (Sultanbeyli Example), Oral Presentation, International Migration and Children, Symposium 17-18 November 2016, Istanbul. 
Masten, A. Effects of War on Children and Child Development, 16.08.2017 tarihinde https://melissainstitute.org/documents/effectsofwar.pdf. Adresinden alınd1.

10.000kayıpÇocuk 13.08.2017 tarihinde www.bbc.com/turkce/haberler/2016 /01/160131 europol 10 bin kayip cocuk adresinden alınd1

Convention on the rights of the child-UNICEF

Other internet sources;

http://www.unhcr.org.ErişimTarihi: 13.08.2017

http://www.unicef.orgErişimTarihi: 13.08.2017

https://en.oxforddictionaries.com/definition/migrationErişimTarihi: 14.08.2017

https://www.iom.int/key-migration-terms ErişimTarihi: 14.08.2017

https://www.ncbi.nlm.nih.gov/pmc/articles/PMC2080482/\# ErişimTarihi: 14.08.2017 